\title{
Örgütsel Adalet Algısı ve Mobbingin İş Tatmini ve İşten Ayrılma Niyetine Etkisinin İncelenmesi
}

\author{
Muhammet Kahrıman ${ }^{1}$, Selen Avc1 ${ }^{2 *}$, Zerrin Aladağ ${ }^{3}$ \\ ${ }^{1}$ Kocaeli Üniversitesi, Mühendislik Fakültesi, Endüstri Mühendisliği Bölümü, Kocaeli, Türkiye, (ORCID: 0000-0002-0111-1111), muhammetkahriman@gmail.com \\ $2^{2 *}$ Kocaeli Üniversitesi, Mühendislik Fakültesi, Endüstri Mühendisliği Bölümü, Kocaeli, Türkiye (ORCID: 0000-0001-7433-5696), selen.avci@kocaeli.edu.tr \\ ${ }^{3}$ Kocaeli Üniversitesi, Mühendislik Fakültesi, Endüstri Mühendisliği x Bölümü, Kocaeli, Türkiye (ORCID: 0000-0002-5986-7210), zaladag@kocaeli.edu.tr
}

(1st International Conference on Applied Engineering and Natural Sciences ICAENS 2021, November 1-3, 2021)

(DOI: 10.31590 /ejosat.994387)

\begin{abstract}
ATIF/REFERENCE: Kahrıman, M., Avcı, S. \& Aladağ, Z. (2021). Örgütsel Adalet Algısı ve Mobbingin İş Tatmini ve İşten Ayrılma
\end{abstract} Niyetine Etkisinin İncelenmesi. Avrupa Bilim ve Teknoloji Dergisi, (28), 164-171.

\section{$\ddot{O} \mathbf{z}$}

Günümüz rekabet koşullarında bilginin kurumsal belleğe aktarılması firmalara rekabet avantajı sağlayan önemli konulardan biridir. Çalışanların edindikleri bilgileri şirketlere kazandırabilmeleri için şirketin çalışan devir hızının düşük olması gerekmektedir. Bu nedenle deneyimli çalışanları kaybetmek kurumsal olmak isteyen firmalar için önemli bir kayıptır. Bu çalışmada, çalışanların örgütsel adalet algılarının ve maruz kaldıkları mobbingin, şirketten ayrılma isteklerine, iş tatminlerine ve işe bağlılıklarına etkisi araştırılmıştır. Bu kapsamda 8'i kişisel bilgiler olmak üzere toplam 59 sorudan oluşan bir anket oluşturulmuş ve ankete farklı sektörlerden 208 kişi katılmıştır. Öncelikle ilişkili olan soruları belirlemek ve boyutları azaltmak için faktör analizi; ardından faktörler arasındaki ilişkileri belirlemek için korelasyon analizi yapılmıştır. Analizden elde edilen sonuçlara göre örgütsel adalet algısındaki artışın iş tatminini olumlu yönde etkilediği ve bu etkinin istatistiksel olarak anlamlı olduğu sonucuna varılmıştır. Araştırmada örgütsel adalet ile mobbing arasında anlamlı bir negatif ilişki bulunmuştur. Dolayısıyla bireylerin maruz kaldığı mobbingin örgütsel adalet algısını olumsuz etkilediği söylenebilir. Korelasyon analizi sonucunda mobbingdeki artışın işten ayrılma eğilimlerini artırdığı ve iş doyumlarını olumsuz yönde etkilediği sonucuna ulaşılmıştır. Anketin son bölümünde, anket katılımcılarından işten ayrılma nedenlerini cevaplamaları istenmiş ve bireylerin işten ayrılmalarına neden olabilecek hususlar arasında etkisi en yüksek olan konunun "yöneticinin tutumu" olduğu belirlenmiştir. Bu durum etkileşim adaleti algısının iş tatmini ve işten ayrılma üzerindeki etkisinin önemini göstermektedir. Ayrıca, işten ayrılma oranının en yüksek olduğu durumun, "işten memnuniyetsizlik" olduğu belirlenmiştir.

\section{Investigation of the Perception of Organizational Justice and the Effect of Mobbing on Job Satisfaction and Intention to Leave of Employment}

\begin{abstract}
Nowadays, transferring information to corporate memory is one of the important issues that provide competitive advantage to companies. Therefore, losing experienced employees is an important loss for companies that want to become corporate. In this study, the effects of organizational justice perceptions of employees and the mobbing they are exposed to on their willingness to leave the company, their job satisfaction and their commitment to work were investigated. In this context, a survey consisting of 59 questions was created and 208 people from different sectors participated in the survey. According to factor and correlation analysis, it was concluded that the increase in the perception of organizational justice had a statistically positive effect on job satisfaction. In the study,
\end{abstract}

\footnotetext{
* Sorumlu Yazar: $\underline{\text { selen.avci@ } @ \text { kocaeli.edu.tr }}$
} 
a significant negative relationship was found between organizational justice and mobbing. Therefore, it can be said that mobbing negatively affects the perception of organizational justice. According to correlation analysis, it was concluded that the increase in mobbing that individuals are exposed to increases their tendency to quit their job and negatively affects their job satisfaction. In addition, survey participants were asked to answer the reasons for leaving the job, and it was determined that the most influential issue among the issues that could cause individuals to leave the job was the attitude of the manager. This situation shows the importance of the effect of interactional justice perception on job satisfaction and turnover. Also, it was determined that the situation with the highest turnover rate was job dissatisfaction.

Keywords: Leave of Employment, Job Satisfaction, Mobbing, Organizational Justice, Factor Analysis, Correlation Analysis.

\section{Giriş}

Örgütler kendilerine özgü kültürlerini oluştururken örgüt içinde hakkaniyetle davranılması gerektiği gerçeğini göz ardı edebilmekte ve bu durum da çalışanların örgütsel adalet algısına zarar verebilmektedir. Adalet kavramı Türk Dil Kurumu tarafindan "Hak ve hukuka uygunluk, hakkı gözetme" olarak tanımlanmaktadır (Türk Dil Kurumu, 2020). İnsanın hayatın her alanındaki adalet arayışı çok eskilere dayanmaktadır. Çalışma hayatına katılımın arttığı son yıllarda bireyler, örgütlerde de bu arayışın içindedir ve bu nedenle olumsuz durumlarla karşılaştıklarında örgütle olan bağları zarar görebilmektedir.

İşten ayrılma niyeti bireyin çalışmakta olduğu örgütteki iş akdini feshetmek kaydıyla işten ayrılma isteğidir (Uslu \& Aktaş, 2017). İşten ayrılma isteğinin ardında birçok neden yer alabilir. $\mathrm{Bu}$ nedenler arasında örgütsel adalet algısının bozulması ve çalışanların şirket içinde maruz kaldığı mobbing uygulamaları da yer almaktadır. Mobbing kavramı farklı isimlerle karşılık bulmasının yanında "yıldırma, bezdirme, duygusal saldırı, duygusal zorbalık" gibi anlamlarda kullanılmaktadır (Usta \& İrge, 2020). Mobbinge maruz kalan kişilerin genel olarak ayırt edici özelliklerinin olmadığı ve bu başlıkta yer alan olumsuz durumlarla herkesin karşılaşabileceği ifade edilmektedir. Örgütün belirlediği hedeflere göre dürüst çalışma, sorgulayıcı, sözlerinin hatalı anlaşılmasından çekinilmesi gibi genel başlıklar mobbinge maruz kalan kişilerde ortak rastlanılan başlıca tutumlardandır (Tutar, 2015). Mobbinge maruz kalan kişilerin strese bağlı olarak baş ve mide ağrısı çektiği gözlenmiştir. Uygulanan mobbingin uzun süreli olması durumunda bu semptomların sendroma dönüşebileceği ifade edilmiştir (Usta \& İrge, 2020).

Mobbing uygulayan kişiler hakkında yapılan araştırmalardan elde edilen sonuçlar, bu kişilerin belirli ortak özellikler taşıdığını göstermektedir. Aşırı kontrolcü bir kişiliğe sahip olma, şişirilmiş benlik ve yönetmeye duyulan açlığın bu kişilerde sıklıkla gözlenen davranışlar arasında yer aldığı belirtilmiştir (Ertürk A. , 2013). Çeşitli araştırmalar mobbing uygulayan kişilerin gerek çocukluk gerek yetişkinlik dönemlerinde fiziksel ve duygusal şiddete maruz kaldığını göstermiştir. Bu kişiler, şirketlerde saygı gören birilerinin de benzer psikolojiyi yaşaması gerektiğini düşünerek bilerek veya bilmeyerek mobbing uygulayabilmektedir.

Literatürde, örgüt içi adalet anlamını taşımakta olan örgütsel adaletin üç temel boyuttan oluştuğu belirtilmektedir. Bu boyutlar dağıtımsal, prosedürel ve etkileşimsel adalettir (Tetik, 2012). Örgütsel adaletin ilk boyutu olan "dağıtımsal adalet"; çalışanlar tarafından ücret, ödül ve terfi gibi kazanımların adil olarak algılanmasını ifade etmektedir (Ünler \& Gürel, 2015). Çalışan elde ettiği kazanımları diğer kişilerle kıyaslama yoluna gider ve adil olmadığını düşündüğünde işe olan bağlılığını kaybedebilir. "Prosedür adaleti" çalışma şartları, performans gibi öğeleri değerlendirirken uygulanan yöntemlerin ve politikaların adil olma düzeyi olarak ifade edilmektedir. Prosedür adaleti daha çok örgüt boyutunda iken dağıtımsal adalet daha kişisel düzeyde sonuçlarla bağlantılıdır (Kılıçlar , 2011). "Etkileşim adaleti” ise yöneticilerin şirket içi kararlarda çalışanlarına karşı dürüst ve saygılı olması olarak tanımlanabilmektedir (Çetinkaya \& Çimenci, 2014).

$\mathrm{Bu}$ çalışmada, örgütsel adalet algısının ve çalışanın maruz kaldığı mobbing uygulamalarının bireyin çalışmakta olduğu örgütten ayrılmasına ve işinden duyduğu tatmine, işine bağlılığına etkisi araştırılmaktadır. Bu amaçla Google Forms üzerinden anket oluşturularak farklı sektörlerde çalışan kişilere ulaşılmış, faktör analizi ile veriler beş boyuta indirgenmiş ve korelasyon analizi ile çeşitli çıkarımlarda bulunulmuştur. Çalışmanın ikinci bölümünde örgütsel adalet algısı ile ilgili literatür araştırması sunulmuş, üçüncü bölümde yöntem ve bulgulara yer verilmiş ve dördüncü bölümünde sonuçlar yorumlanmıştır.

\section{Yazın Taraması}

Bu bölümde, çeşitli sektörlerde örgütsel adalet algısı ile ilgili yapılmış çalışmalara literatürden örnekler verilmiştir. Şahin ve Taşkaya (Şahin \& Taşkaya, 2010), Adana'da faaliyet gösteren bir kamu hastanesi çalışanlarına yönelik araştırmalarında sağlık çalışanlarının örgütsel adalet anlayışları ve bunu etkileyen faktörlerin belirlenmesi üzerine çalışmışlardır. Çalışmada yapısal eşitlik modelinden faydalanılarak analizler yapılmıştır. Analizler sonucunda örgüt içindeki adalet olgusunun kişilerin hizmet süreleri, aylık nöbet sayıları, eğitim düzeyleri, bakılan hasta sayısı ve yönetici olma durumu ile ilişkili olduğu görülmüştür. Kurum içinde ödül-ceza sisteminin adil uygulanması, yöneticilere verilecek sorumlulukların adil paylaştırılması ve çalışanların karar verme süreçlerine katılımının artırılması ile örgütsel adalet algısının artırılabileceği yönünde öneriler sunulmuştur. Çetinkaya ve Çimenci (Çetinkaya \& Çimenci, 2014), yapısal eşitlik modellemesini kullanarak Afyonkarahisar'da faaliyetini sürdüren alışveriş merkezi işletmelerinde örgütsel adaletin üç boyutunun örgütsel vatandaşlık davranışının beş farklı boyutuna etkisini ve örgütsel özdeşleşmenin aracılık rolünü araştırmıştır. Veriler doğrultusunda, örgütsel adaletin artmasının örgütsel özdeşlemeyi pozitif yönde anlamlı olarak etkilediği, örgütsel adalet ve örgütsel vatandaşlık davranışında örgütsel özdeşlemenin tam aracılık rolüne sahip olduğu tespit edilmiştir. Çalışmada, analiz sonuçları tartışılarak işletmelerde çalışma programlarının adil dağıtılması, objektif kararlar alınması, çalışan katılımının sağlanması, politikaların daha şeffaf ve açık olması ile örgütsel adaletin artırılabileceği yönünde öneriler sunulmuştur. Özsungur (Özsungur, 2017), Adana ilinde bulunan 26 farklı işletmedeki insan kaynakları yöneticisini örneklem kabul ederek örgütsel adaleti analiz etmiştir. Buna göre etkileşim, mahrumiyet adaleti ve prosedürel adaletin insan kaynakları yöneticileri üzerindeki etkilerinin işletmedeki pozisyona, eğitim düzeyine ve cinsiyete göre farklılığı Anova ve korelasyon analizleri ile incelenmiştir. Analizlere göre eğitim düzeyi, cinsiyet ve işletmedeki pozisyon bakımından anlamlı fark olmadığı sonucuna varılmıştır. Anova 
testi orta düzeydeki yöneticiler için mahrumiyet algısının fazla olduğunu, üst düzey yöneticilerde prosedürel adalet algısının daha yüksek olduğunu göstermiştir. Yapılan bu tespitlere yönelik; farklı coğrafya ve kültürlerde örgütsel adalet algılarının araştırılması, işletme içi eğitimler ve yöneticilerin örgütsel adalet anlayışını geliştirecek uygulamalar yapılması gibi bazı önerilerle çalışma tamamlanmıştır. Yılmaz ve Doğan (2017), sağlık kurumlarında mobbing davranışının örgütsel adalet algısına etkisini araştırdığı çalışmasında Bolu İzzet Baysal Eğitim ve Araştırma Hastanesi'ndeki 230 çalışana anket uygulamıştır. Sonuç olarak, örgütsel adalet algısının mobbing davranışına anlamlı etkisi olmadığı sonucuna varılmıştır. Ayrıca analizlerden, adalet algısında olumsuzluklar olduğu sonucu elde edilmiştir. Kurumda çalışanların adalet algılarını olumlu yönde geliştirmek için ödüllendirme sisteminin eşit olması, ücretlendirme, karar verme süreçlerine katılım ve çalışma saatlerinde düzenleme gibi uygulamalar ile çalışanlara adil yaklaşım sergilenmesi konusunun önemi vurgulanmıştır. Bağcı ve Demir (2017), Akdeniz Üniversitesi rektörlüğüne bağlı olarak çalışan 199 idari personele uyguladıkları anket ile rektörlük çalışanlarının iş tatminlerine örgütsel adalet algılarının etkisini araştırmıştır. Elde edilen veriler üzerinden regresyon ve korelasyon analizi yapılmıştır. Regresyon analizi sonucunda; çalışanların iş tatmini üzerinde etkileşim ve prosedürel adaletin anlamlı etkisi görülürken dağıtım adaletinin anlamlı bir etkisi görülmemiştir. Analizlerin sunduğu bilgiler 1şığında çalışanların karar verme süreçlerine katılımın artırılması, görev dağılımlarında ve terfilerde liyakate daha fazla önem gösterilmesi gerektiği ve motivasyon artıcı çeşitli faaliyetlerde bulunmanın iş tatminini artırabileceği yönünde öneriler sunulmuştur. Bayarçelik ve Fındıklı (2017), İstanbul'da faaliyet göstermekte olan kamu ve özel banka çalışanları arasından 371 kişiye yaptıkları anket çalışmasında örgütsel adaletin banka çalışanlarının işten ayrılma eğilimlerine etkisini ve yapılan işin tatmin düzeyinin etkileşimdeki aracılık rolünü incelemiştir. Hiyerarşik regresyon analizinden elde edilen sonuçlar, işe olan tatmin düzeyinin dağıtımsal ve etkileşimsel adaletin işten ayrılma eğilimi üzerinde kısmi aracılık etkisi olduğunu göstermiştir. Çalışmada, dağıtımsal ve etkileşimsel adalet algısının artmasının çalışanların işten ayrılma niyetini azalttığı sonucuna ulaşılmıştır. Literatürde yapılan birçok çalışmadan elde edilen sonuçlara paralel olarak, örgütsel adalet algısı yüksek olan çalışanların iş yapma performanslarının arttığı ve işten ayrılma eğilimlerinin azaldığ 1 belirtilmiştir. Ertürk ve Erdirençelebi (2018), Konya'da faaliyet gösteren iki kamu bankasında çalışanların işyerindeki yalnızlığı ile işten tatmini ve bunların işten ayrılma niyetleri arasındaki ilişki boyutunu araştırmıştır. Yapılan korelasyon analizi, faktör analizi ve yapısal eşitlik modellemesine göre örgüt içinde yaşanan yalnızlığın işe duyulan tatmini azalttığı ve işten ayrılma sürecini tetiklediği sonuçlarına ulaşılmıştır. Örgüt içi iletişim kanallarının ve faaliyetlerin artırılması yönünde öneriler sunulmuştur. Etkin ödüllendirme sisteminin oluşturulması, liyakate dayalı terfi imkanlarının geliştirilmesi, iş birliğine önem verilmesi gibi konularla iş tatmininin arttırılabileceği ve bunun sonucunda işten ayrılma niyetinin azaltılabileceği ifade edilmiştir. Yılmaz ve Bilir Güler (2018), örgütsel vatandaşlık davranışına etkisi olduğu düşünülen örgütsel adalet algısını analiz etmek üzere bir aile şirketinde çalışan 27 kişi ile görüşme yapmış, verileri betimsel analiz yöntemi ile analize tabii tutmuştur. Analizlere göre şirket çalışanlarının çoğunda örgütsel adalet algısının yüksek olduğu ve örgütsel vatandaşlık davranışı sergileme eğilimine yatkın olduğu görülmüştür. Örgütsel adaleti yetersiz bulan çalışanlar ise örgütsel vatandaşlık davranışı sergilemekte isteksiz olduklarını ifade etmiştir. Ulutaş (2018),
Konya'da faaliyet göstermekte olan 19 işletme çalışanına uyguladıkları anket ile çalışanların iş doyumu ve işten ayrılma ile örgütsel adalet algısı arasındaki ilişkiyi incelemiştir. Anketlerden elde edilen verilere regresyon, korelasyon ve faktör analizleri yapılmış; örgütsel adaletin dağıtımsal ve prosedürel boyutlarının iş tatmini ile arasında pozitif yönde anlamlı ilişki olduğu, işten ayrılma niyeti ile negatif yönde anlamlı ilişki olduğu görülmüştür. Çalışanların işten ayrılma eğilimlerinin azaltılabilmesi konusunda işletmelerde uygulanan ücret, terfi, ödüllendirme gibi konuların herkesçe algılanır ve uygulanabilir şekilde belirlenmesi konusuna vurgu yapılmıştır. İyidemirci ve Aydıntan (2018), Ankara Ostim Organize Sanayi Bölgesinde faaliyet gösteren işletmelerde çalışan 110 kişilik örneklem grubu üzerinden çalışanların motivasyonu, örgütsel vatandaşlık davranışı ve işten ayrılma niyeti arasındaki ilişkileri incelemiştir. Analizler sonucunda motivasyon ile örgütsel vatandaşlık davranışı arasında pozitif ve anlamlı ilişki olduğu, motivasyon ve örgütsel vatandaşlık davranışı ile işten ayrılma niyeti arasında negatif ve anlamlı ilişki olduğu görülmüştür. Korelasyon sonuçları doğrultusunda, motivasyon seviyesi yüksek olan çalışanların görev ve sorumlulukları dışındaki işlerde işletmelere katkı sağlama eğilimine sahip oldukları yorumu yapılmıştır. Analizlere farklı boyutlar eklenerek genişletilmesinin ve bu yönde çalışmalar yapılmasının literatüre katkı sağlayacağı bildirilerek çalışma sonlandırılmıştır. Doğan (2018), Afyonkarahisar'da faaliyet gösteren beş yıldızlı termal otellerde 254 kişiye yaptıkları anket doğrultusunda örgütsel adaletin alt boyutlarının iş yapma performansına etkisini araştırmıştır. Korelasyon analizi ile iş performansı ile örgütsel adalet arasında istatistiksel açıdan anlamlı pozitif bir ilişki olduğu sonucuna ulaşılmıştır. Farklı sektör ve işletmeler için benzer analizlerin yapılması önerilmiştir. Ercan, Kazançoğlu ve Küçükaltan (2019) telekomünikasyon sektöründeki satış temsilcileri ile yaptıkları mülakatlar ile çalışma şartlarının görece zor olduğu satış alanında iş stresi, iş tatmini, ödüllendirme konularının işten ayrılma ile ilişkisi incelemiştir. Veriler QSRNvivo programı ile incelenerek haritalandırılmıştır. Analizlerden elde edilen sonuçlara göre iş stresine en çok etkisi olan konuların yönetici unsuru, iş yükü ve hedef baskısı olduğu sonucuna varılmıştır. Ödüllendirme, ücret ve yan hakların iş tatmine etkisi tespit edilmiştir. Çalışmada örneklem uzayının az olması sebebi ile kapsam genişletilerek daha anlamlı sonuçlara ulaşılabileceği önerilmiştir. Akbaba (2019), turizm işletmelerinde çalışan toplam 294 kişilik örneklem üzerinden gerçekleştirdiği bir anket çalışmasında çalışanların yeşil örgütsel davranış üzerinde örgütsel adalet algısının etkisini araştırmıştır. Anketler üzerinden yapılan regresyon analizi sonucunda en düşük olarak algılanan örgütsel adalet boyutunun dağıtımsal adalet olduğu; bilgilendirme ve prosedürel adaletin ise en yüksek adalet boyutları olduğu sonucuna varılmıştır. Ayrıca analiz sonuçlarında yeşil örgütsel davranışın örgütsel adaletten anlamlı düzeyde etkilendiği görülmüştür. Çalışanların örgütsel adalet anlayışlarının olumlu seviyede olduğu, yöneticilerin çalışanlara pozitif yaklaşım sergiledikleri, çalışanların ise inisiyatif alarak çevresel boyutlar kapsamında kâğıt, su ve enerji israfını engelleyici çalışmalara katılım gösterdikleri sonucuna ulaşılmıştır. Köksal ve Gürsoy (2019)'un çalışmasında özel bir işletmede 224 kişinin katılımı ile elde edilen veriler doğrultusunda istismarcı yönetim tutumunun işten ayrılmaya etkisi ve bu etkide örgütsel etik boyutlarının aracılığ incelenmiştir. Regresyon ve korelasyon analizleri ile hipotezler kurularak test edilmiştir. Analizlerden yöneticinin istismarcı davranışının çalışanların işten ayrılma düşüncesini artırdığı ve örgütsel etik kavramlarının işten ayrılmaya etkisi olduğu sonucuna varılmıştır. Bunun yanı sıra örgütsel etik 
ilkelerinin düşük olmasının istismara maruz kalan çalışanın işten ayrılma meylini artırdığı tespit edilmiştir. Dolayısıyla işletmelerde istismarcı yöneticinin etkisini ve işten ayrılma niyetini düşürmek için örgütsel etik ilkelerinin güçlü olması gerektiği vurgusu yapılmıştır. Pehlivan Kurnaz ve Oruç (2019), tekstil sektöründe faaliyet gösteren işletme çalışanlarına yönelik yaptıkları çalışmada örgütsel adaletin iş tatmini ile olan ilişkisini incelemiştir. Toplam 112 kişiye ulaşılarak elde edilen anket yanıtları faktör analizi ile değerlendirilmiş ve örgütsel adalet boyutlarının birbiriyle ilişkisi bulunmuştur. Örgütsel adalet yaklaşımı ile iş tatmini arasında pozitif bir ilişki olduğu korelasyon analizi ile tespit edilmiştir. Ayrıca araştırmadaki çalışanların üstlendikleri rollere göre örgütsel adalet boyutlarının değişebileceği belirtilirken eğitim düzeyi ile örgütsel adalet algısı arasında farklılık olmadığı sonucuna ulaşılmıştır. Yıldız ve Atilla (2019), Denizli ilinde faaliyet gösteren 191 termal otel çalışanına uyguladıkları anket ile çalışanların örgütsel adalet algılarının örgüte bağlılık düzeylerine etkisini araştırmıştır. Anket sonuçları regresyon, Anova ve korelasyon analizi ile incelenerek örgütsel bağlılığa örgütsel adalet algısının etkisi olduğu sonucuna ulaşılmıştır. Çalışanların örgütsel bağlılığını artırmanın iş performansına olumlu etki edip iş devri hızını düşüreceği bu nedenle örgütsel adalet algısının artırılmasının önemli olduğu ifade edilmiştir. Yılmaz (2019), elektrik sektörüne dair çalışmasında örgütsel bağlılığın ve örgütsel adalet algısının işten ayrılma düşüncesi ile ilişkisini 146 katılımcının dahil olduğu anket çalışması ile incelemiştir. Veriler SPSS paket programı ile korelasyon, regresyon ve faktör analizlerine tabii tutularak ilgili konuların işten ayrılmaya etkileri olduğu sonucuna varılmıştır. İşe bağlılığın artırılması için üst yönetimin yenilik akımlarına öncülük edilmesine dair öneriler sunulmuştur. Doğan, Aktemur, Uzgör ve Yeloğlu (2020), havacılık sektöründe çalışanlar üzerinde yaptıkları araştırmada iş tatmininin aracılık etkisini ve bu etki türünün, örgütsel adalet algısı ile işten ayrılma üzerindeki ilişkiye etkisini araştırmıştır. Toplam 154 kişiye uygulanan anket sonuçları analiz edilmiş, iş tatmininin örgütsel adaletin tüm alt boyutlarında işten ayrılmalarda negatif ve anlamlı tam aracılık etkisine sahip olduğu tespit edilmiştir. Dolayısıyla çalışanlarda iş tatmininin artmasının işten ayrılmaları azalttığ 1 sonucuna varılmıştır. Analiz sonuçlarına göre havacılık sektöründe çalışanların iş tatminlerini artırmaya yönelik öneriler sunularak çalışma sonlandırılmıştır. Örücü, Korkmaz ve Kırboğa (2020), örgütsel adalet algısının şirket içi vatandaşlık davranışına etkisinde örgüt kültürünün rolünü tespit etmek amacıyla Balıkesir ili Erdek ve Marmara ilçelerinde sağlık müdürlüğüne bağlı birimlerde çalışanlara anket uygulamıştır. Hiyerarşik regresyon analizi sonucunda örgüt kültürünün etkisi tespit edilerek örgütsel vatandaşlık davranışlarının artmasına yönelik ödül ve terfi süreçlerinin objektif konulara dayandırılması, çalışanların karar verme sürecine katılımı gibi öneriler sunulmuştur. Usta ve İrge (2020), çalışanların maruz kaldığı mobbingin örgütsel adalet algısına ve kişilerin işten ayrılma fikrine etkisinin araştırılması için 200 kişilik örnekleme anket uygulamıştır. Elde edilen veriler SPSS paket programı yardımı ile analize tabii tutularak etkilerin anlamlılık düzeyleri ölçülmüştür. Yapılan analizler doğrultusunda mobbing ile işten ayrılma arasında orta düzeyde pozitif yönlü ve anlamlı ilişki tespit edilirken örgütsel adalet ile mobbing arasında yine orta düzeyde ancak negatif yönlü ilişki olduğu sonucu bulunmuştur. Örneklemin artırılması ve araştırma kapsamının genişletilmesi önerileri sunularak çalışma tamamlanmıştır.

\section{Yöntem ve Bulgular}

Çalışma kapsamında farklı sektörlerde çalışan 208 kişiye 8'i cinsiyet, medeni durum, eğitim düzeyi, yaş, iş deneyimi, çalışılan sektör ve gelir aralığ 1 gibi kişisel bilgileri içeren toplam 59 anket sorusu yöneltilip örgütsel adalet anlayışının ve işyerinde maruz kalınan mobbingin iş tatmini ve işten ayrılma eğilimine etkisi araştırılmıştır. Araştırmada 5'li Likert ölçeği kullanılarak anket verileri katılımcılardan elektronik ortamdan temin edilmiştir. Anketin oluşturulma ve verilerin katılımcılardan temin edilme aşamasında Google Forms uygulaması kullanılmıştır. Anket soruları düzenlenirken aşağıdaki çalışmalar referans alınmıştır:

- Mobbingin ve örgütsel adaletin işe bağlilık ve işten ayrılmaya etkisi (Kaya, 2016),

- İșten yıldırma, stres ve tükenmişlik ile iş tatmini ve işten ayrılma arasındaki ilişki (Ülbeği, 2016),

- Örgütsel davranışların iş performansına ve işten ayrılma niyetine etkisi (Başaran, 2016),

- Çalışma kalitesi ile işten tatmini, örgüte bağlılık ve işten ayrılma niyeti arasındaki ilişki (Altay, 2018),

- Örgütsel adalet ve vatandaşlık davranışının çalışan performansına etkisi (Kantarcıoğlu, 2019).

Anket analizine aykırı değer analizi ile başlanmıştır. Buna göre ankette yer alan aykırı (uç) değerler tutarsızlık olmaması adına anket verilerinden çıkartılmıştır.

Ankete katılım sağlayan toplam 208 kişinin demografik bilgilerinin dağılımı Tablo 1'de yer almaktadır. Tablo 1'deki bilgilere göre katılımcıların \%43,3'ü kadın, \%56,7'si erkektir. \%45,2 oranında Evli - Çocuklu kişiler ve \%57,7 ile lisans mezunları çoğunluğu oluşturmaktadır.

Tablo 2'de ankette yer alan sorulara dair Faktör Analizi (FA) sonuçları yer almaktadır. Anketteki 51 sorunun analizini kolaylaştırma adına değişken sayısının azaltılması hedeflenmiştir. Aralarında ilişki bulunan soruları belirlemek ve değişken (boyut) indirgemek için FA yapılmıştır. Tablo 2'ye göre 1. faktörde 14 madde yer almakta olup faktör yükleri 0,592 ile 0,829 arasında değişkenlik göstermektedir. S1-S14 aralığındaki tüm maddeler 1. faktörde yer almaktadır. Benzer yorumlar diğer faktörler için tabloda görülmektedir. 3 veya daha az maddenin bir boyutta toplanma durumu, faktör yüklerinin uygun dağılmadığı durumlar elimine edilerek 5 soru FA'dan çıkartılmış ve kalan 46 soru Tablo 2'de yer aldığ üzere 5 faktöre (boyut) indirgenmiştir. Boyutların belirlenmesi aşamasında faktör yüklerinin 0,30 değerinden yüksek olması ve dağılım gösterdiği yükler arasındaki farkın 0,10 değerinden yüksek olması kabulüne göre boyutlandırma yapılmıştır (Büyüköztürk, 2019). Dolayısıyla Tablo 2'de birden fazla faktöre dağılan konular arasında anlamlı farklılık olmadığı için (dağılan boyutlar arası farklılık 0,10 değerinden büyük olmaması) ilgili maddeler analizden çıkartılmamıştır. FA yapılırken sıkıştırma metodu olarak temel bileşenler analizi (Extraction Method: Principal Component Analysis), döndürme metodu olarak Oblimin yöntemi (Rotation Method: Oblimin with Kaiser Normalization) kullanılmıştır. Bu 5 faktörün değişkenliği açıklama oranı \%49,5 olarak hesaplanmıştır. 
Tablo 1. Araştırmaya Katılan Kişilerin Demografik Bilgileri

\begin{tabular}{|c|c|c|c|c|c|}
\hline Demografik Özellikler & Siklık & Yüzde & Demografik Özellikler & Siklık & Yüzde \\
\hline Cinsiyet & & & Tecrübe - Mevcut İsyeri & & \\
\hline Kadın & 90 & 43,3 & Çalışmıyorum & 13 & 6,3 \\
\hline Erkek & 118 & 56,7 & $0-3$ aras1 & 93 & 44,7 \\
\hline Medeni Durum & & & 4-6 aras1 & 52 & 25,0 \\
\hline Bekar & 73 & 35,1 & $7-11$ arasi & 32 & 15,4 \\
\hline Evli & 41 & 19,7 & $12-15$ aras 1 & 5 & 2,4 \\
\hline Evli - Çocuklu & 94 & 45,2 & 15 üzeri & 13 & 6,3 \\
\hline Eğitim Düzeyi & & & Tecrübe - Toplam & & \\
\hline Önlisans & 23 & 11,1 & Çalışmıyorum & 5 & 2,4 \\
\hline Lisans & 120 & 57,7 & $0-3$ aras 1 & 24 & 11,5 \\
\hline Lisans Üstü & 65 & 31,3 & 4-6 arasi & 65 & 31,3 \\
\hline Yaş & & & $7-11$ aras1 & 63 & 30,3 \\
\hline $18-24$ & 12 & 5,8 & $12-15$ aras 1 & 16 & 7,7 \\
\hline $35-30$ & 63 & 30,3 & 15 üzeri & 35 & 16,8 \\
\hline $31-35$ & 59 & 28,4 & Sektör & & \\
\hline $36-40$ & 36 & 17,3 & Otomotiv - Ana Sanayi & 14 & 6,7 \\
\hline $41-50$ & 29 & 13,9 & Otomotiv - Tedarikçi & 61 & 29,3 \\
\hline 50 üzeri & 9 & 4,3 & Sağlık ve Sosyal Hizmetler & 18 & 8,7 \\
\hline Gelir & & & Kamu & 16 & 7,7 \\
\hline $3.000-4.500$ & 63 & 30,3 & İnşaat, Yap1 & 17 & 8,2 \\
\hline $4.501-6.000$ & 51 & 24,5 & Danışmanlık & 11 & 5,3 \\
\hline $6.001-8.000$ & 39 & 18,8 & Diğer & 71 & 34,1 \\
\hline $8.001-10.000$ & 21 & 10,1 & & & \\
\hline 10.000 üzeri & 34 & 16,3 & & & \\
\hline Toplam & 208 & 100 & Toplam & 208 & 100 \\
\hline
\end{tabular}

Tablo 2. Faktör Analizi Sonuçlart

\begin{tabular}{|ccccc|}
\hline Faktör & Soru Aralığı & Soru SayıSI & En Düşük Faktör Yükü & En Yüksek Faktör Yükü \\
\hline 1 & S1- S14 & 14 & 0,592 & 0,829 \\
2 & S15-S19 & 5 & 0,404 & 0,602 \\
3 & S20-S32 & 12 & 0,473 & 0,701 \\
4 & S33-S44 & 10 & 0,372 & 0,750 \\
5 & S45-S51 & 5 & 0,353 & 0,780 \\
\hline
\end{tabular}

Tablo 3'te Kaiser-Meyer-Olkin (KMO) ve Barlett testi sonuçları paylaşılmıştır. Örneklem yeterlilik değeri 0,869 olarak hesaplanmıştır. $\mathrm{Bu}$ değerin 0,70'in üzerinde olması testin güvenilir olduğunu göstermektedir. Küresellik testinde $p$ değerinin 0,05 'in altında olması sebebiyle elde edilen güvenirlik değeri anlamlı olarak yorumlanmaktadır. Anket verilerinden elde edilen bilgilerin güvenirliği Cronbach Alfa Katsayısı yöntemi ile test edilerek analiz edilmiştir. Cronbach Alfa (CA) değerinin 0,50'nin altında olması ölçeğin güvenilirliğinin düşük olduğunu ve yeniden düzenlenmesi gerektiğini ifade etmektedir. 0,50-0,60 aralığında olması düşük güvenirliği, 0,60-0,70 aralığında olması yeterli güvenirliği, 0,70-0,90 aralığında olması ölçeğin yüksek güvenilirliğe sahip olduğunu ve güvenle kullanılabileceğini belirtmektedir. 0,90 üzerindeki değerler ise ölçeğin çok yüksek güvenilir seviyesinde olduğunu göstermektedir (Özdamar, 2019).
Tablo 3. KMO ve Barlett Test Sonuçları

\begin{tabular}{|c|cc|}
\hline $\begin{array}{c}\text { Kaiser-Meyer-Olkin } \\
\text { Örneklem Yeterlilik Testi }\end{array}$ & \multicolumn{2}{|c|}{0,869} \\
\hline \multirow{4}{*}{ Bartlett Küresellik Testi } & $\begin{array}{c}\text { Yaklaş1k } \\
\text { Ki-Kare } \\
\left(\chi^{2}\right)\end{array}$ & 5075,26 \\
\cline { 2 - 3 } & $\begin{array}{c}\text { Serbestlik } \\
\text { Derecesi }\end{array}$ & 1035 \\
\cline { 2 - 3 } & $\mathrm{p}$ & 0,000 \\
\hline
\end{tabular}

Tablo 4'te yer alan verilere göre, soru sayısı az olan Örgütsel Vatandaşlık Davranışı (ÖVD) boyutu için bulunan CA değeri düşük güvenirliği ve İşten Ayrılma (İA) boyutu için bulunan değer ise yeterli güvenirliği ifade etmektedir. Örgütsel Adalet (ÖA), 
Mobbing (MB), İş Tatmini (İT) boyutu ve anketin tamamı için bu değer 0,70 'ten büyük olduğu için ölçeğin yüksek güvenirliğe sahip olduğu yorumu yapılabilir. Tüm değişkenler FA ile 5 boyuta indirgenerek ölçeklerin güvenilir olduğu hesaplanmıştır. Araştırmaya konu olan bu boyutlar arasında varsa ilişkilerin anlaşılması ve yorumlanabilmesi için Pearson Korelasyon (PK) Analizi yapılmıştır.

Tablo 4. Anket Güvenilirlik İstatistikleri

\begin{tabular}{|c|l|c|c|}
\hline Boyut & \multicolumn{1}{|c|}{ Açıklama } & CA & Soru Sayısı \\
\hline Boyut 1 & Örgütsel Adalet & 0,935 & 14 \\
\hline Boyut 2 & $\begin{array}{l}\text { Örgütsel Vatandaşlık } \\
\text { Davranışı }\end{array}$ & 0,510 & 5 \\
\hline Boyut 3 & Mobbing & 0,867 & 12 \\
\hline Boyut 4 & İş Tatmini & 0,855 & 10 \\
\hline Boyut 5 & İşten Ayrılma & 0,647 & 5 \\
\hline Anket & - & 0,783 & 46 \\
\hline
\end{tabular}

Tablo 5, belirlenen 5 faktörün birbirleri ile ilişkisini göstermektedir. PK satırı ilişskinin düzeyini ifade ederken $\mathrm{p}$ satırı ise ilişkinin istatistiki olarak anlamlılı̆̆ını ifade etmektedir. İlişkinin anlamlı olması için p değerinin 0,05 'ten küçük olması gerekmektedir (Özdamar, 2019). Tablo 5'e göre, örgütsel adalet ile örgütsel vatandaşlık davranışı arasında 0,21 düzeyinde pozitif anlamlı ilişki bulunduğu görülmektedir. Benzer olarak örgütsel adalet ile mobbing arasında 0,45 oranında negatif yönde anlamlı ilişki tespit edilmiştir. Dolayısıyla Tablo 5'te yer alan verilere göre; bireylerin örgütsel adalet algısının artmasının maruz kaldıkları mobbingin azalması ile 0,45 oranında ilişkili olduğu yorumu yapılabilir. Araştırmanın konularından biri olan örgütsel adaletin iş tatmini ile ilişkisi de 0,46 oranında pozitif yönlü olarak bulunmuştur; örgütsel adalet algısının artmasının iş tatminine pozitif yönde anlamlı etkisi olduğu görülmektedir. Tablo 5'te mobbingin işten ayrılmaya 0,16 oranında etkisi olduğu görülmektedir. Bireylerin mobbinge maruz kalmaları işten ayrılmalarına anlamlı olarak etki ettiği sonucuna varılmıştır. Bunun yanı sıra mobbinge maruz kalan bireylerin iş tatmininin 0,48 oranında negatif yönlü etkilendiği sonucu Tablo 5'te görülmektedir.

Tablo 5. Boyutlar (Faktörler) Arası Korelasyon Analizi

\begin{tabular}{|c|c|c|c|c|c|c|}
\hline Boyut & & ÖA & ÖVD & MB & IT & İA \\
\hline \multirow{2}{O}{$A$} & $P K$ & 1 &, $21^{* *}$ &,$- 45^{* *}$ &, $46^{* *}$ & $-0,02$ \\
& $p$ & & 0,00 & 0,00 & 0,00 & 0,73 \\
\hline \multirow{2}{*}{$O V D$} & $P K$ & & 1 & $-0,01$ & 0,13 & 0,06 \\
& $p$ & & & 0,94 & 0,06 & 0,37 \\
\hline \multirow{2}{*}{$M B$} & $P K$ & & & 1 &,$- 48^{* *}$ &, $16^{* *}$ \\
& $p$ & & & & 0,00 & 0,02 \\
\hline \multirow{2}{*}{$I T$} & $P K$ & & & & 1 & $-0,12$ \\
& $p$ & & & & & 0,10 \\
\hline \multirow{2}{*}{$I A$} & $P K$ & & & & & 1 \\
& $p$ & & & & & \\
\hline
\end{tabular}

Anket çalışmasında yanıtlayıcılara 59 soruya ilaveten çoklu cevap verebilecekleri işten ayrılma nedenleri sorularak yanıtlamaları istenmiştir. Çoklu yanıtlama analizi ile kişilerin işten ayrılmalarına sebep olan veya olabilecek nedenleri seçmeleri istenmiştir.

Bireylerin işten ayrılmalarına sebep olabilecek konular Tablo 6'da özetlenmiştir. Buna göre tekil etkisi en yüksek olan konunun $\% 10,1$ ile örgütsel adaletin etkileşimsel boyutunun ilgi alanı olan yöneticinin tutumu olduğu görülmektedir. Bireylerin işten ayrılmalarında yöneticilerin direkt etkisinin yanında mevcut işte memnuniyetsizliğe sebep olacağı dolaylı etki ile bu oran daha yüksek olacaktır. Bu durum, etkileşimsel adalet algısının kişilerin iş tatminine ve işten ayrılmaya etkisinin önemini göstermektedir. Yöneticinin tutumunu sırasıyla örgütsel adaletin dağıtımsal ve prosedürel boyutlarında yer alan ücret ve şirket içi adalet başlıkları izlemektedir. Tablo 6'da yer alan alt sebepler 4 başlıkta özetlendiğinde işten ayrılmalarda en yüksek orana sahip olan mevcut işten duyulan memnuniyetsizlik, toplam cevapların \%62,2'sini oluşturmaktadır. Bireylerin mevcut işteki memnuniyetsizliğini azaltmak ve iş tatminini artırmak için işletme yöneticileri, örgütsel adalet algısını iyileştirmeye yönelik politikalar geliştirmenin yanı sıra bireylere gelişim imkânı sağlamaya, ekip içi dengelerin ve uyumluluğun sağlanmasına yönelik geliştirici faaliyetler gerçekleştirmeleri çalışan devir hızını düşürme yönünde önemli adımlar olacaktır. Bireylere dış firmalarca sunulan kariyer ve diğer imkanların işten ayrılma eğilimine etkisi \%20,2 olarak tespit edilmiştir. İşletme içi kariyer firsatlarının ve çalışma şartlarının iyileştirilmesine yönelik çalıştaylar, seminerler ve benchmark faaliyetleri iş tatminini arttırarak işten ayrılma niyetini azaltabilir. Özel sebeplerden dolayı işten ayrılmaların etkisi \%9,3 oranında iken mücbir sebepler başlığında işten ayrılmanın etkisi \%8,3 oranındadır. Mevcut işteki politikaların ve kariyer fursatlarının geliştirilmesinin yanında çalışanların kişisel sorunlarına çözüm bulmaya yönelik faaliyetler işten ayrılma eğilimini azaltarak iş tatminini artıracak konular arasında yer almaktadır.

\section{Tartışma, Sonuç ve Öneriler}

Bu çalışmada, bireylerin örgütlerde maruz kaldığı mobbing uygulamalarının ve örgüt içi adalet algısının işten ayrılma niyetine ve iş tatminine olan etkisi araştırılmıştır. Bu kapsamda Google Forms aracılığg ile hazırlanan anket soruları online olarak katılımcıların kullanımına sunularak 208 kişiden veri toplanmıştır. Elde edilen bu veriler IBM SPSS 25.0 paket programı yardımıyla çeşitli analizlere tabi tutulmuştur. Çalışmadan elde edilen sonuçlara göre örgütsel adalet algısında yaşanan artışın iş tatminini pozitif yönde etkilediği ve bu etkinin de istatistiksel olarak anlamlı olduğu sonucuna ulaşılmıştır. Ulutaş (2018), Pehlivan Kurnaz ve Oruç (2019) çalışmalarında örgütsel adaletin iş tatminine pozitif etkisini tespit etmişlerdir. Bağcı ve Demir (2017) örgütsel adalet boyutlarının iş tatminine etkisini araştırdığı çalışmada araştırma sonucuna paralel tespitler elde etmişlerdir. Çalışmada örgütsel adalet ile maruz kalınan mobbing arasında negatif yönlü anlamlı ilişki olduğu tespit edilmiştir. Dolayısıyla bireylerin maruz kaldığ 1 mobbing uygulamalarının örgütsel adalet algısına olumsuz etkisi olduğu söylenebilir. Usta ve İrge (2020) çalışmalarında örgütsel adalet ile mobbing arasında negatif yönlü ilişki sonucuna ulaşmışlardır. 
Tablo 6. Issten Ayrılma Alt Sebepleri Oranları

\begin{tabular}{|c|c|c|c|c|}
\hline Sebep & İşten Ayrılma Alt Sebepleri & $\begin{array}{l}\text { Cevap } \\
\text { Sayısı }\end{array}$ & Yüzde & $\begin{array}{l}\text { Toplam } \\
\text { Yüzde }\end{array}$ \\
\hline \multirow{8}{*}{$\begin{array}{l}\text { Mevcut İșten } \\
\text { Tatminsizlik }\end{array}$} & Yöneticinin tutumu & 181 & $\% 10,1$ & \multirow{8}{*}{$\% 62,2$} \\
\hline & Ücretin düşük olması & 162 & $\% 9,1$ & \\
\hline & Şirket içi adil olmayan ücret ve terfi yaklaşımı & 154 & $\% 8,6$ & \\
\hline & Gelişim imkanlarının yetersiz olması & 132 & $\% 7,4$ & \\
\hline & Terfi imkanlarının yetersizliği & 125 & $\% 7,0$ & \\
\hline & Stres seviyesi ve yoğunluğun fazla olması & 135 & $\% 7,6$ & \\
\hline & Ekip içi uyumsuzluklar & 123 & $\% 6,9$ & \\
\hline & Yapılan işin değersiz hissettirmesi & 102 & $\% 5,7$ & \\
\hline \multirow{3}{*}{ Yeni Firsatlar } & Yeni işin sunduğu yüksek ücret & 142 & $\% 8,0$ & \multirow{3}{*}{$\% 20,2$} \\
\hline & $\begin{array}{l}\text { Yeni işin sunduğu kariyer firsatı (yöneticilik - müdürlük } \\
\text { vb) }\end{array}$ & 121 & $\% 6,8$ & \\
\hline & Yeni işin sunduğu esnek çalışma firsatları & 94 & $\% 5,3$ & \\
\hline \multirow{3}{*}{ Özel Sebepler } & İşyerine ulaşım problemi & 68 & $\% 3,8$ & \multirow{3}{*}{$\% 9,3$} \\
\hline & İşyerine / şehre uyum sorunu & 34 & $\% 1,9$ & \\
\hline & Şirketin dünya görüşü ile uyumsuzluğu & 62 & $\% 3,5$ & \\
\hline \multirow{3}{*}{$\begin{array}{l}\text { Zaruri } \\
\text { Sebepler }\end{array}$} & Evlilik / sağlık / ailevi durumlar & 59 & $\% 3,3$ & \multirow{3}{*}{$\% 8,3$} \\
\hline & Kendi işini yapacak olmak & 55 & $\% 3,1$ & \\
\hline & $\begin{array}{l}\text { Karşı1ıklı fesih anlaşması (işten çıkartılma - emeklilik } \\
\text { vs) }\end{array}$ & 37 & $\% 2,1$ & \\
\hline & Toplam & 1.786 & $\% 100$ & \\
\hline
\end{tabular}

Yapılan analizler sonucunda bireylerin maruz kaldıkları mobbingin artmasının işten ayrılma eğilimini artırdığ 1 ve iş tatminini 0,48 oranında negatif yönde etkilediği sonuçlarına ulaşılmıştır. Korelasyon analizleri ile bahsi geçen ilişkilerin istatistiksel açıdan anlamlı oldukları tespit edilmiştir. Yılmaz (2019) araştırmasında örgütsel adalet algısının işten ayrılmaya etkisi olduğu sonucuna ulaşmıştır.

Elde edilen bu sonuçlara göre şirket yöneticilerinin, çalışanların örgütsel adalet algısını ve iş tatmininin artırılması yönünde faaliyetlere önem vererek çalışanların işten ayrılma eğilimlerini azaltabilecekleri görülmektedir. Şirket içindeki ücret, terfi ve ödül gibi dağıtımsal adalet politikalarının yanında tüm örgütsel adalet boyutlarının standartlarla yönetilmesi çalışanların örgütsel adalet algısını artırmaya yönelik bir faaliyet olacaktır. Bunun yanı sıra yönetici tutumlarının ve mobbing uygulayan kişilerin davranışları analiz edilerek uygun olmayan davranışların altında yatan gerekçelerin çözülmesi çalışanların maruz kaldıkları mobbing uygulamalarının azalmasını sağlayarak iş tatminini artırıp işten ayrılma eğilimini azaltacaktır. Firma içindeki yeni kariyer olanaklarının ve çalışma şartlarının iyileştirilmesi için sektördeki firmalara dair yapılacak çalıştay ve analizler çalışanların iş tatminin artarak işten ayrılma eğilimini azaltacak diğer faaliyetler arasındadır. Bireylerin yaşadığı kişisel sorunların çözümüne yönelik klinik destek sağlanması, başarısızlık durumlarında yeteneklerinin gözden geçirilerek uygun işe yönlendirilmesi ve işe uygunluk adına yetenek gelişiminin sağlanması yine işten ayrılmaları azaltacak faktörler arasındadır.

Çalışmaya konu olan araştırma farklı sektörlerde çalışanlara yönelik yapılmıştır. Çalışmanın kapsamı belirli bir organize sanayi bölgesindeki firmalarla sınırlandırılabileceği gibi aynı e-ISSN: 2148-2683 sektörde faaliyet gösteren şirketlere yönelik de yapılarak analiz edilebilir. Bu durumda bölgenin veya sektörün kendi dinamiğinin etkisi ortadan kaldırılmış olacaktır. Bunun yanı sıra çalışma, belirli bir firma özeline indirgenip işten çıkış mülakatlarında sorulara yanıtlar alınarak şirket içi örgütsel adalet algısı, mobbing ve bunların iş tatmini ile ișten çıkıș eğilimine etkisi araştırılabilir. Elde edilen bilgiler analizler edilip firma özelinde somut önlemlerle örgütsel adalet algısı ve işe bağllık artırılıp mobbing uygulamaları ve işten ayrılmalar azaltılarak firmanın kurumsallaşmasına katkı sağlanacağı gibi işgücü kaybının azaltılması ile milli servetin etkin kullanımına da katkı sağlanmış olacaktır.

\section{Kaynakça}

Akbaba, M. (2019). Örgütsel Adalet İşgörenlerin Yeşil Örgütsel Davranışını Etkiler Mi? Trakya Üniversitesi Sosyal Bilimler Dergisi, 21(2), 641-660.

Altay, M. (2018). Çalışma Yaşam Kalitesinin İş Tatmini, Örgütsel Bağlllık ve İşten Ayrılma Niyeti ile İlişkisinde İş Yükü ve Lider-Üye Etkileşiminin Rolü. Isparta: Süleyman Demirel Üniversitesi Sosyal Bilimler Enstitüsü.

Bağcı, Z., \& Demir, G. (2017). Örgütlerde Adalet Algısının İş Tatmini Üzerine Etkisi: Akdeniz Üniversitesi İdari Personeli Üzerinde Bir Araştırma. Manas Journal of Social Studies, 6(4), 343-357.

Başaran, R. (2016). Çalışanların Örgütsel Tutum ve Davranışlarının İş Performansı ve İșten Ayrılma Niyeti Üzerine Etkisi: Psikolojik Sözleşmelerin Aracılık Rolü. İstanbul: Beykent Üniversitesi Sosyal Bilimler Enstitüsü. 
Bayarçelik, E. B., \& Fındıklı, M. (2017). İş Tatmininin, Örgütsel Adalet ve İşten Ayrılma Niyeti İlişkisindeki Aracılık Rolü. Beykent Üniversitesi Sosyal Bilimler Dergisi, 10(1), 16-31.

Büyüköztürk, Ş. (2019). Sosyal Bilimler İçin Veri Analizi El Kitabı (26 b.). Ankara: Pegem Akademi.

Çetinkaya, M., \& Çimenci, S. (2014). Örgütsel Adalet Algısının Örgütsel Vatandaşlık Davranışı Üzerindeki Etkisi ve Örgütsel Özdeşleşmenin Aracılık Rolü: Yapısal Eşitlik Modeli Çalışması. Yönetim Bilimleri Dergisi, 12(23), 237-278.

Doğan, H. (2018). Örgütsel Adalet Algısı ile İş Performansı Arasındaki İlişki. Kastamonu Üniversitesi İktisadi ve İdari Bilimler Fakültesi Dergisi, 20(8), 26-46.

Doğan, Ü., Aktemur, Ş., Uzgör, M., \& Yeloğlu, H. (2020). Türkiye'de Havacılık Sektörü Çalışanlarında Örgütsel Adaletin İşten Ayrılma Niyetine Etkisinde İş Tatmininin Aracılık Rolü: Kesitsel Bir Araştırma . Journal of Aviation Research, 2(1), 26-44.

Ercan, A., Kazançoğlu, İ., \& Küçükaltan, B. (2019). İş Stresi, İş Tatmini, Örgütsel Kıvanç ve İşten Ayrılma Niyeti Etkileşiminin İş Performansıyla İlintisi. Journal of Yasar University, 19, 101-114.

Ertürk, A. (2013). Yıldırma Davranışları, Nedenleri ve Sonuçları. Bartın Üniversitesi Eğitim Fakültesi Dergisı̇, 2(1), 146-169.

Ertürk, E., \& Erdirençelebi, M. (2018). Çalışanların Örgütsel Yalnızlık Algısının İş Tatmini ve İşten Ayrılma Niyeti Üzerine Etkileri. Gaziantep University Journal of Social Sciences, 17(2), 603-618.

İyidemirci, H., \& Aydıntan, B. (2018). Motivasyon, Örgütsel Vatandaşlık Davranışı ve İşten Ayrılma Niyeti Arasındaki İlişkinin Belirlenmesine Yönelik Bir Araştırma; Ostim Organize Sanayi Bölgesi Örneği. Gazi İktisat ve Işsletme Dergisi, 4(3), 131-144.

Kantarcıoğlu, N. (2019). Örgütsel Adalet ve Örgütsel Vatandaşlık Davranışının İşgören Performansına Etkisi: Ankara'daki Kobilerde Bir Araştırma. İstanbul: İstanbul Gelişim Üniversitesi Sosyal Bilimler Enstitüsü.

Kaya, N. (2016). Mobbingin Örgütte Adalet Alg1sı ve Örgütsel Bağlılık İlişkisi ile Çalışanların İş Performansına ve İşten Ayrılma Niyetine Etkisi. Beykent Üniversitesi Sosyal Bilimler Enstitüsü. İstanbul: Beykent Üniversitesi Sosyal Bilimler Enstitüsü.

Kilıçlar , A. (2011). Yöneticiye Duyulan Güven ile Örgütsel Adalet ilişkisinin Öğretmenler Açısından İncelenmesi. İsletme Araştırmaları Dergisi, 3(3), 23-36.

Köksal, K., \& Gürsoy, A. (2019). İstismarcı Yönetimin İşten Ayrılma Niyetine Etkisinde Örgütsel Etik İlkelerin Düzenleyici ve Aracı Rolü. Manisa Celal Bayar Üniversitesi Sosyal Bilimler Dergisi, 17(2), 347-366.

Örücü, E., Korkmaz, E., \& Kırboğa, R. (2020). Örgütsel Adalet Algısının Örgütsel Vatandaşlık Davranışına Etkisinde Örgüt Kültürünün Rolü . Ekonomik ve Sosyal Araştırmalar Dergisi, 16(1), 197-218.

Özdamar, K. (2019). Paket Programlar ile Istatistiksel Veri Analizi (11 b., Cilt 1). Eskişehir: Nisan Kitabevi.

Özsungur, F. (2017). İnsan Kaynakları Yöneticilerinin Örgütsel Adalet Algıları Üzerine Ampirik Bir Çalışma. Insan ve Toplum Bilimleri Araştırma Dergisi, 6(5), 2574-2593.

Pehlivan Kurnaz, İ., \& Oruç, İ. (2019). Örgütsel Adalet ve İş Tatmini Arasındaki İlişkinin İncelenmesi Üzerine Uygulamalı Bir Araştırma. Kırklareli Üniversitesi Sosyal Bilimler Dergisi, 3(3), 375-390.

Şahin, B., \& Taşkaya, S. (2010). Sağlık Çalışanlarının Örgütsel Adalet Algılarını Etkileyen Faktörlerin Yapısal Eşitlik Modeli
İle İncelenmesi. Hacettepe Sağlık İdaresi Dergisi, 3(2), 85114.

Tetik, S. (2012). Kamu İşletmelerinde Çalışanların Örgütsel Adalet Algılarının Bazı Demografik Özellikler Açısından İncelenmesi. Organizasyon ve Yönetim Bilimleri Dergisi, 4(1), 239-249.

Tutar, H. (2015). Mobbing Nedenleri ve Başa Çıkma Stratejileri: Kuramsal Yaklaşım. Ankara: Detay Yayıncılık.

Türk Dil Kurumu. (2020, Arallk 30). https://sozluk.gov.tr

Ulutaş, M. (2018). Örgütsel Adalet Algısının Çalışanların İş Doyumu ve İşten Ayrılma Eğilimine Etkisi. Manas Journal of Social Studies, 7(2), 333-352.

Uslu, S., \& Aktaş, H. (2017). İşten Ayrılma Niyeti İle Örgütsel Sessizlik Etkileşiminde İş Güvencesi Memnuniyeti ve İş Güvencesi Endeksinin Aracı Rolü: Özel Bir Hastane Çalışanları Üzerinde Bir Araştırma. Eskişehir Osmangazi Üniversitesi IBF Dergisi, 12(1), 141-160.

Usta, F. N., \& İrge, N. T. (2020). Mobbingin Örgütsel Adalet Algısı Ve İşten Ayrılma Niyeti Üzerine Etkisi: Bir Emlak Konut Şirketi Örneği . Research Studies Anatolia Journal, 3(3), 237-249.

Ülbeği, İ. D. (2016). Yıldırma, İş Stresi, Tükenmişlik, İş Tatmini ve İşten Ayrılma Niyeti Arasındaki İlişkiler: Görgül Bir Araştırma. Adana: Çukurova Üniversitesi Sosyal Bilimler Enstitüsü.

Ünler, E., \& Gürel, H. (2015). Örgütsel Adaletin Peşinde. İstanbul: Beta Basım Yayım.

Yıldız, A., \& Atilla, G. (2019). Örgütsel Adalet Algısının Örgütsel Bağl1lık Düzeyine Etkisi: Otel Çalışanları Üzerinde Bir Araştırma. Bartın Üniversitesi İktisadi ve İdari Bilimler Fakültesi Dergisi, 10(19), 39-64.

Yılmaz, A. C., \& Bilir Güler, S. (2018). Örgütsel Adalet Ve Örgütsel Vatandaşlık Davranışı Arasındaki İlişkinin Anlamlandırılması: Bir Aile İşletmesinde Nitel Araştırma. Trakya Üniversitesi Iktisadi ve İdari Bilimler Fakültesi Dergisi, 7(1), 36-52.

Yılmaz, B. (2019). Örgütsel Bağl1lık Ve Örgütsel Adaletin İşten Ayrılma Niyetine Etkileri Üzerine Bir Araştırma: Elektrik Sektöründe Bir Uygulama. Stratejik ve Sosyal Araştırmalar Dergisi, 3(1), 181-202.

Yılmaz, M., \& Doğan, S. (2017). Sağlık Kurumlarında Örgütsel Adalet Algısının Mobbing Davranışları Üzerine Etkisi: Bolu'da Bir Uygulama. Kahramanmaraş Sütçü İmam Üniversitesi İktisadi ve İdari Bilimler Fakültesi Dergisi, 7(1), 67-94. 